\title{
How Do Non-native Speakers of Arabic Language Acquire and Learn Morphology in Arabic? Evidence from Analysis of Three Young Acquirers: An Argentinean and Two Beninois
}

\author{
Ahmed Mohammed Saleh Alduais \\ Department of English Language, King Saud University (KSU) \\ Riyadh, Saudi Arabia
}

Tel: 966-551-367-208Ｅ-mail: ibnalduais@yahoo.com

Received: September 21, 2012 Accepted: October 16, 2012 Published: December 1, 2012

doi:10.5296/ijl.v4i1.2432ＵRL: http://dx.doi.org/10.5296/ijl.v4i1.2432

\begin{abstract}
Purpose: To describe the earliest and latest morphological elements acquired by non-native speakers of Arabic language.

Methods: Three young non-native speakers (a Spanish and two Beninois) were tape-recorded, twenty-minutes each and tested based on traditional classification of words in Arabic: nouns-class, verbs-class, and function-words class. Face-to-face observations were also noted down.

Results: Results indicated that case-one had many problems regarding plurality, duality, gender, agreement between adjectives and nouns, number in general except simple numbers when used separately. Case-two produced a large number of the content-words, but again with many atypical ones. Case-three had only a few errors in patterns like broken-plural and diminutives. Additionally, case-one demonstrated a limited use of verbs, a very few or no function-words, case-two showed a quiet number of verbs compared to case one's poor use of verbs, and function-words as well, and case-three proved to have good command of nouns-class, verbs-class and function-words-class.

Conclusions: Cases 1-3 are alike yet dissimilar in terms of acquired and non-acquired morphological patterns. These variances were shown clear through the produced morphological patterns by each and may be affected by the period spent in the Saudi Arabia
\end{abstract}


and amount of language each one of them has been exposed to.

Keywords: Arabic language, Morphology acquisition, Noun-words class, Verb-words class, Function-words class 


\section{Introduction}

How language is acquired in general is a very fascinating yet mysterious topic that linguists and specialists from other fields struggle to know. Yet, what is more fascinating and mysterious is acquiring or/and learning a second language by L2 acquirer and/or learner. This study focused on morphology acquisition and/learning by $\mathrm{L} 2$ learners. It is an embedded-multiple-case study, where in three cases whose first languages are different have been recorded and then the data-collected have been analyzed in terms of similarities and dissimilarities among acquired morphological patterns.

Actually, it is being observed that both acquirers and learners of Arabic language as a second language (ASL) face many problems during acquisition and learning processes. However, one of the major problems which non-native speakers meet is acquiring and learning the morphology of Arabic language, that is, they may come and leave to any of the Arab countries, with same problems. Due to this, it is worthwhile to investigate this area which will help first to see how this component of language is acquired or/and learned by young non-native speakers of Arabic language, and also to decide on the nature of the difficulties met by such L2 acquirers/learners of the Arabic language.

Very little data has been written about the acquisition of morphology in Arabic by L2 learners or/and acquirers. Following this claim, the researcher does this research with the hope that it will draw the attentions of other researchers to work in this field and investigate such area.

\subsection{First Language Acquisition}

How each and every one of us acquires his/her first language is still an unanswerable question till now. In spite of the made attempts and theories which have been evolved explaining such world phenomenon; they all have reached questionable findings, controversial conclusions, even if they are plausible. However, from the major theories of first language acquisition can be mentioned here to help then explaining theories of second language acquisition in relation to this research-paper.

Generally, the major language acquisition theories are four, namely: behaviourims, innatism, interactionsim, and connectionism. Skinner who was pioneer in proposing this approach assumes that language is acquired through imitation which then develops into habits. Later on, these habits will go under practice and then the language is formulated. However, this approach has greatly succeeded in interpreting what goes on when a child acquires the first language in simple linguistic levels but not complex ones. For that matter, a new theory has evolved proposed by Chomsky. Chomsky thinks from an innate perspective that a child's brain is not a blank slate which is filled by imitation, habits and practice concluded by language behavior. Instead, a child mind is biologically prepared with a universal grammar, more accurately as Chomsky describes it Language Acquisition Device (LAD) which enables him/her to acquire the language used in his/her society just like any other process like walking for example. To continue this argument, interactionists like Slobin, Piaget, Vygotsky and others argue that language acquisition mechanism can be explained in terms of cognitive development. For Piaget, for example, language is developed just like other cognitive 
abilities are being developed; he uses terms like (egocentric) ability of the child for explaining him/herself. Dissimilar to this opinion, yet following the same approach, Vygotsky claims that it is social interaction rather than psychological or cognitive as Piaget has described it which can describe the mechanism of first language acquisition. Well, for connectionists (e.g. Jeffrey Elman), they will argue against both Chomsky and Piaget and Vygotsky who actually have in common in having the idea that language requires a separate module in the mind. So, for a connectionist, language is acquired through exposure to as many associations to a linguistic pattern as possible.

To conclude, the above mentioned theories, mainly their findings, still beyond the real, plausible and enough interpretation for first language acquisition, yet they have served a lot and still are helping many researches to works on their results to develop language pedagogy, teaching and learning language, etc.

\subsection{Second Language Acquisition and Learning Theories}

Principally, acquiring a second language is entirely and externally different from acquiring a first language, though some would think they would go under the same processes. Despite this, this claim is controversial for the same theories used to explain first language acquisition are actually the same which are being used to explain second language acquisition, albeit, each first language acquisition theory in second language acquisition is being extended with the help of an additional hypothesis/hypotheses as it will be shown below.

To start with behaviourism, in second language acquisition, it has been proposed and emphasized to be applicable for second language acquisition by both Nelson Brooks and Robert Lado. Lado hypothesizes in his proposed model Contrastive Analysis Hypothesis $\mathrm{CAH}$ that similar patterns in two languages will be learned and/or acquired more easily than different patterns in two languages which will be learned and/or acquired more difficultly. Furthermore, what Brooks and Lado have called as mimicry and memorization towards formation of habits has been criticized later by those who prefer to follow Chomsky's theory for explaining second language acquisition.

In comparison and with reference to the above criticism for both behaviourims and second $\mathrm{CAH}$, those who consider Chomsky's theory offers the best view for explaining second language acquisition support this biasness with a worth number of researches. For instance, Lydia White and Cook, assumes that second language acquisition has also a kind of logical acquisition just as it happens in the first language acquisition [Cook]. Again, what happens in the first language acquisition regarding Universal Grammar is applicable to happen in the second language acquisition, [White]. Another supporter for the Chomskyan perspective include who Krashen proposes the monitor model which consists of five hypotheses to explain second language acquisition, namely, 1) acquisition-learning hypothesis, 2) monitor hypothesis, 3) natural order hypothesis, 4) input hypothesis, and 5) affective filter hypothesis.

One more perspective towards explaining second language acquisition following the interactionists' approach is information processing. Actually, in this approach, there different models: 1) Norman Segalowitz: learners should pay attention to what they want to learn 
and/or acquire from among the presented linguistic patterns, 2) Anderson, DeKeyser and some others: second language acquisition starts with Declarative Knowledge which has to be developed into Procedural Knowledge by practice and learning processes, and 3) Transfer Appropriate Processing: learners store, retrieve language patterns in similar situations that the first language was acquired.

Models derived and/or have been proposed depending on the connectionism theory, are also competitive in their views regarding second language acquisition. Consider, for example, Ellis's emphasis on frequency and input of features a learner being exposed to. Actually and according to this model, learners do not only learn, rather they have the ability of making generalizations and predictions about the second language they are acquiring. One more model is the Competition Model, described by Bates and MacWhinney in terms of approaching both meaning and form. Say it another way, it is only by exposing learners to thousands of meanings of what they are learning so that meaningful connections are formulated.

Additionally, three other models influenced by the cognitive/developmental perspective are: 1) the interaction hypothesis: Long support this hypothesis; we learn through interaction, correct feedback, etc., 2) the noticing hypothesis: Schmidt proposed this hypothesis, supported by Susan Gass also; unless we notice what we want to learn, we will not learn it, and 3) the processability theory: proposed by Meisel, Clahsen, and Pienemann and developed by the last one; there is a certain system for transfer of first language knowledge to second language acquisition by learners.

The last theory for second language acquisition to be mentioned here is the socio-cultural perspective influenced by the Vygotskyan theory mainly Zone Proximal Development ZPD. Lantolf explained this model using what he called as Collaborative Interaction. Similar to Lantolf are Swain and Lapkin who introduced Collaborative Dialogue with the help of socio-cultural perspective; learners acquire second language by being involved in productive language aspects/tasks/skills.

\subsection{Arabic Language}

Basically and with reference to comparative linguistics, Arabic language is one of the Semitic languages. Originally, Arabic language has at least five forms: Classical Arabic Language (refers to the language of the Holy Quran and the language which was used in the pre-Islam period, Islam period, etc., Standard Arabic Language (refers to the language which has been used mainly from the times after Abbassi period), Modern Standard Arabic Language (refers to the language which is used in media in nowadays, and language used by sophisticated people, Spoken Arabic (used by day-to-day communication among all native speakers of Arabic language in all the countries where in Arabic language is used as the first language[all dialects of Arabic), and Foreign Arabic Language (used by learners of Arabic language either as second or for specific purposes, as it happens in the case of non-native speakers of Arabic who are Muslims), [it should be noted that there is always exception, some non-native speakers can speak Arabic language better than Arab themselves]. Linguistically, Arabic language is majorly an inflectional language from a morphological perspective, case-marking 
dependent from a synaptic point of view, from right to left writing, graphically, [more details about the linguistic system of Arabic will be provided below when accounting for the morphology of Arabic language).

In principle, Spanish language is one of the Romance languages family, the sister of languages like French, Italian, etc.. Spanish language is used and spoken in different countries including: Spain, Costa Rica, Cuba, Dominican Republic, Mexico, Guatemala, Honduras, El Salvador, Nicaragua, Panama, Colombia, Venezuela, Ecuador, Peru, Bolivia, Chile, Argentina, Paraguay, Uruguay, United States, and Puerto Rico.

Like Spanish language, French language is also one of the Romance languages family. Actually, French language is used as both a mother-tongue language in 30 countries distributed around Europe, Africa, North America, and Oceania. Additionally, it is also used as an official language in other dependent entities and territories in Asia, Oceania, Africa, North America, Europe, and Antarctica (Africa). Needless to say, from among the countries where in French is used as an official language of the country is Benin, a Wes African country.

Dendi or Dandawa as one of the Songhay dialects language which is one the Nilo-Sahran languages, a minor one actually which according to Dalby (2004) has no 'close relatives', (p. 572), is the mother language of people in some areas in northern Benin, Niger and Nigeria. For Dendi language, they use the Latin script, just like French, and Spanish which have make use also of the Latin scrip but with French and Spanish variants for both language. Unlike these three languages, in the case of Arabic language: Arabic and Syriac alphabets are used in addition to the Latin script in the writing system of Arabic language.

Linguistically, Arabic like other languages has its own unique features and shared features with other languages as any other language in the world. For instance, graphically it has 28 eight letters written from right to left starting with [aalif] and ending with [yaa]. Phonetically, Arabic mainly Standard Arabic has 30 consonants and 6 vowels; three short and three long. Phonologically, Semitic languages in general and Arabic as one of them is characterized pharyngeal and guttural sounds, again with major sounds and minor vowels. Syntactically, the typical structure of the sentence in the form of statement in Standard Arabic Language is $(\mathrm{V}+\mathrm{S}+\mathrm{O} / \mathrm{Comp}$.$) with allowance of (\mathrm{S}+\mathrm{V}+\mathrm{O})$.

Morphologically, Arabic language is a root-pattern inflectional language. Ryding, (2005) defines morphology as the linguistic level system which 'pertains to the organization, rules, and processes concerning meaningful units of language, whether they be words themselves or parts of words, such as affixes of various sorts', (p. 44). In Arabic however, the study of morphology refers to two things: one is derivational or lexical morphology and this refers exactly to word formation, and inflectional morphology which in turn refers to interaction of these words with syntax.

Morphology as a component of language acquired by a child in his/her childhood in whatever language can be problematic for a learner when it is either acquired or learned by a person as a second morphology. In spite of this fact, when it comes to native speakers children who 
have certain language disorder such as those with specific language impairment (SLI) one stands surprised wondering whether such problems mainly morphological ones can be similar to those a second language learner will meet when learning or acquiring this the morphology of this or that certain language. Thus, the following are five studies which have been conducted in different settings, environments, and with different objectives and research methodologies, but all share the idea of searching in morphology acquisition in L2 learners and/or acquirers. It should be noted that these five studies are arranged here by data of publication starting by the most recent one.

To start with Shirai's (2010) study, s/he accounts for the acquisitions of tense-aspect morphology suing empirical data to support the claim(s) of this paper. Therefore, accounting for the interaction of the two aspects of past tense acquisition, namely, semantic bias in early past tense marking and the regular/irregular asymmetry in the acquisition of past tense morphology, and testing the claim of both Pinker (1984) and Bickerton (1981) which provide specific predictions regarding how verb semantics and regularity interact in the acquisition of tense-aspect systems, were the main objectives of this study. Hereby, some major conclusions which the researcher has come up with are: 1) overregularization is observed even at the stage when the morphology is restricted to its semantic prototype, 2) in L1 acquisition, there is no clear pattern of regular-irregular dissociation in past tense acquisition, and there are individual variations, and 3) in L2 acquisition, it is argued that there is some evidence for regular-irregular dissociation in relation to semantic bias, regular morphology being more strongly tied to semantics, but the evidence is not conclusive.

This study by both Jacobson and Schwartz also accounts for morphology acquisition in comparison and contrast, that is, between normal children whose native tongue is not English (it is Spanish) and children with language impairment who again learn and acquire English as a second language. Major conclusions of this study are: 1) overall accuracy was higher for children in the TD group on all verbs types, 2) TD children produced regular verbs with $80 \%$ accuracy, irregular verbs with $47 \%$ accuracy, and novel verbs with $49 \%$ accuracy, 3 ) children with LI produced regular verbs with $11 \%$ accuracy, irregular verbs with $28 \%$ accuracy, and novel verbs with 5\% accuracy, 4) the groups differed in the overall accuracy of past tense use according to verb type and the types of errors produced, and 5) children with LI performed proportionally and absolutely lower than their TD peers on all verb categories which indicates that TD children performed better than their LI peers.

One more study is by Paradis (2005) who investigates the claim whether errors and/or mistakes made by L2 learners and/or acquirers are similar to those made by person with language disorders. However, in this paper he presents data for longitudinal studies of cases from different nationalities living in Canada. The paper has been concluded with the following indications: 1) the ESL children in this study seemed to be learning English at variable individual rates, 2) early ESL children can be expected to make errors with grammatical morphology, and these errors can extend into their second year of experience speaking the language, 3 ) difficulties in producing grammatical morphology will be evident regardless of L1 background, although there is some indication that difficulties may be more pronounced in children whose L1 is not RI language, such as Mandarin or Cantonese, 4) 
difficulties in producing grammatical morphology will be more pronounced for morphemes that mark the grammatical category tense, like auxiliary verb and verb inflections with the exception of [-ing], and when children make errors they usually omit them more often than substitute the wrong morpheme, 5) ESL children will alternate between correct use and omission of a morpheme in their speech until they gradually achieve native-speaker accuracy levels with them, 6) such characteristics which describe typical English-language learning overlap largely with the characteristics of monolingual impaired language, and 7) it is advisable to be cautious when considering the presence of errors with grammatical morphology as a sign of SLI in early ESL children.

In addition to the studies which have been mentioned above about morphology acquisition by L2 acquirers is Parodi, Schwartz and Clahsen's (2004) study who explore some morphological aspects acquisition mainly L2 acquisition of the morpho-syntax, but not of English language, it is about German nominal instead. Thus, the researchers attempted investigating the acquisition of morpho-syntax by adult L2 speakers of German whose native languages are: Korean, Turkish, Spanish and Italian [Romance], compared after that to those of L1 speakers of German language. the study is concluded with that: 1) in early stages, plurality is often expressed via lexical, uninflected forms, as determined by the high ratio of quantifiers and numerals to other D-elements, 2) while there is some noun plural inflection present at this point, the incidence of noun plural morphology increases over time, 3) there were only few clear cases of (attempted) number concord in nominals, even at more advanced stages of L2 development, 4) the role of L1 transfer in adult L2 acquisition is greatly valid in the findings of this study, 5) adults L2 acquirers with subject-verb agreement, plural inflection, etc., in their L1 grammars do not have an advantage in the acquisition of similar TL Phenomena over L2 learners who do not, 6) adults L2 learners, despite having structurally different L1s, behave in much the same way towards inflectional morphology, 7) regardless of the L1 inflectional systems of the L2 learners, they essentially start from the same point in regard to acquiring inflectional morphology, and 8) a general indication of this study seems to be that in both the nominal and the sentential domains, syntactic transfer is in evidence but morphological acquisition is problematic regardless of the properties of the L1.

Last but not least, Jia (2003) also attempts for the acquisition of plural morpheme by native Chinese-speaking children. In spite of this and unlike the above mentioned studies, this study had no atypical children, though the researcher has accounted for this issue analytically, that is, by reviewing, discussing and inferring predicted results and generalizations from results of previous studies about the acquisition of morphology compared to children with language impairment. In brief and according to the results of this study, errors made by the participants of this study can be classified into: required omitted errors RO and OG errors; the former ones constituted the majority of errors that occurred; whereas in the latter types all participants made OG errors documented in the L1 acquisition, again within this type there are two sub-types: obligatory and non-obligatory plural contexts, yet in each sub-type, there sub-sub-types. Moreover, the results of this research also indicate that variable performance in different task situations was another aspect in which L1 and L2 learners differed. Moreover, L2 learners made similar types of OG errors as L1 learners do in both obligatory plural and 
non-plural contexts. More generally, there are some similarities and differences between L2 learners and L1 learners with SLI in various aspects of plural morpheme acquisition.

\section{Methods}

\subsection{Participants}

The participants in this study are three young non-native speakers of Arabic language. They are from different countries and even continents. Actually, one of them is an Argentinean whose first language L1 is Spanish. The other two are Beninese, but one his first language is Dendi and the second one his first language is French. Needless to say, both the two Beninese do speak French language with difference that is for one of them it is his first language and for the second one it is his second language. So, these three are actually students of Arabic language. Thus, the students have three different levels: one is in level 1 , the second is in level 2 and the third has graduated and is preparing to join any department to obtaining a bachelor degree.

\subsubsection{Sample}

The researcher has followed the stratified sampling technique for selecting the participants in this study. In other words, the students are actually grouped in their classes when learning Arabic into four levels, because they study for four years as a diploma for learning the Arabic language. So, only three groups have been identified first: level one, level two and level four (about to graduate or have just graduated). Then, the researcher has selected a case from each group since this study is a case and large number of participants will not allow for detailed description and investigation of the chosen topic. Of course, each one is from a different nationality or if from the same nationality, his mother tongue language is different from the language of his peer.

\subsubsection{Case 1}

Case 1 who is 30 years old Argentinean is a scholarship student at King Saud University, College of Arts, Department of Arabic Language and Literature, Institute of Arabic Language for Non-Native Speakers. He has come to learn Arabic language, a diploma for two years according to the designed programme in this institute. His mother-tongue language is Spanish, the first language in Argentina. According to IAS, he was not able to speak Arabic language or use it in day-to-day communication except using it for religious purposes, that is, reciting some verses of the Holy Quran and performing the prayers as he is Muslim and embracing this religion requires knowing Arabic language. Till now, IAS has spent about a year in the Kingdom of Saudi Arabia, (Arabic native-speakers country). Needless to say, IAS and all other cases are learning and acquiring the Modern Standard Arabic as most of their exposure is to language performed by teachers who communicate with them mostly with the MSA. Finally, IAS knows also English and can use it effectively as his second language which means, Arabic for him now is as a third language prospectively.

\subsubsection{Case 2}

Case 2 is the second case in this study; he is 25 year old Beninion. Like the IAS, he has come 
to the Kingdom as a scholarship student for the purpose of studying Arabic language. In other words, he is being enrolled in the same programme just like IAS. His mother-tongue language is Dendi or Dandawa, and his second language is French, which is the official language in the whole Benin. Again, like IAS, HBD has not learnt Arabic formally before coming to the Kingdom, except being able to use it for performing the prayers as a Muslim and reciting verses from the Holy Quran. Unlike IAS who is still in level 2, HBD is now in the $3^{\text {rd }}$ level. At last, HBD is also like IAS, he is learning and acquiring Arabic language as a third language as his first is Dendi and second is French language.

\subsubsection{Case 3}

Case 3 is the third participant in this study and he is 22 years old. He is Beninion, but his mother-tongue language is French. Once again, he has come to the Kingdom as a scholarship student of Arabic language. He can use English language as a foreign language. Compared to his peers, he is the most advanced one regarding Arabic language acquisition and learning; he has finished his diploma with excellent grade.

\subsubsection{Setting}

This study has been conducted in the Department of English Language and Literature, Applied Linguistics Section, College of Arts, King Saud University, Riyadh, Kingdom of Saudi Arabia, early 2011. Moreover, the participants in this study are students of Arabic language as a second language ASL in the Institute of Arabic Language for Non-native Speakers, College of Arts, King Saud University, Riyadh, Kingdom of Saudi Arabia. The cases have been interviewed and recorded after taking their permission, each in his own room, in the Students' Housing Campus, King Saud University.

\subsection{Measures}

Two techniques have been used for data-collection for this study, namely personal interviews (spontaneous speech) and designed questions for eliciting data about morphology acquisition and/or learning. Each one of the participants has been recorded for 20 minutes, yet has been given a five minutes to say/talk about anything he prefers. The extra five minutes for spontaneous speech were not recorded, instead observed mistakes and/or errors were noted down immediately.

\subsection{Design}

This research-paper is an embedded-multiple-case-study (a number of cases are introduced relatively to form an embedded unit of research or idea) where in the researcher has followed the approach of case-study research. Yet, the study is an explanatory one, rather than descriptive and exploratory since the subjects were reachable and accessible.

\subsection{Procedures}

However, the students were recorded using a mobile recorder. The researcher, then, has first sent the data via Bluetooth device to the laptop, then transcribing it in Arabic. After that, the data has been translated into English, mean language of writing this research paper. Finally, 
this study is actually purely qualitative which is natural in the case study approach.

The researcher has followed the parallel procedure during data-collection for this study. Say it another way, all the three cases who are the main source for the data of this study have been identified earlier before starting the study. Of course, this was on the basis that they all share the concerned topic in this research, that is, morphology acquisition and/or learning in Arabic language by L2 learners.

With reference to what has been mentioned above (tools and measures), the researcher has first transcribed the data. Secondly, the data was translated into English language taking into consideration (the morphological aspects of Arabic language will not change or will not be affected after translation). Then, the researcher, has made a map-draft, that is, classifying morphological elements by topic, classifying correct uses and wrong uses, classifying the wrongs uses according to degree of difficulty of the misused morphological element, and finally searching for differences and similarities among the three cases. To this end, the researcher then has attempted both intuitive and inductive analysis, yet discussion for the data towards certain conclusions to answer the raised questions in this study.

\section{Results}

In each case, two tables will be presented. Say it another way, the first table in each case will show samples of typical morphological produced items. The second table shows samples of atypical morphological produced items, (all shaded tables represent atypical produced morphological patterns).

Tables (1-6) represent the selected data of case one where tables (1-3) illustrate samples of typical produced morphological patterns and tables (4-6) illustrate samples of atypical morphological patterns. Again, tables $(1 \& 4)$ are examples for the noun class, tables $(2 \& 5)$ are examples for the verb class, and tables $(3 \& 6)$ are examples for the function words class. Thus, each column to the right in each table shows English translation of the example, and each column in each table to the left shows the original example in Arabic language.

Table 1. Typical produced patterns in nouns class

\begin{tabular}{|c|c|}
\hline Example in Arabic Language & English translation of the Example \\
\hline هما إيفان و عبد الكريم & They are Iffan and Abdulkarim. \\
\hline أنا في المستوى الثالث & I am in the $3^{\text {rd }}$ level. \\
\hline 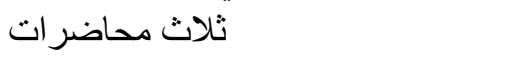 & three lectures \\
\hline في طريقتين للعمل & There are two ways for getting a job. \\
\hline ل كن مسلم يمني & buy a Yemeni Muslim \\
\hline الحاسوب فقط & computer only \\
\hline 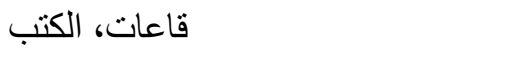 & classes, books \\
\hline 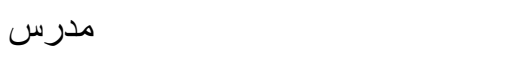 & a teacher \\
\hline سورة صغيرة & a short Surah \\
\hline بنيني، صو مالي، صيني & Beninion, Somali, Chinese \\
\hline
\end{tabular}




\section{Macrothink}

Table 2. Typical produced patterns in verbs class

\begin{tabular}{|c|c|}
\hline Example in Arabic Language & English translation of the Example \\
\hline لم أدرس & I have not studied before. \\
\hline 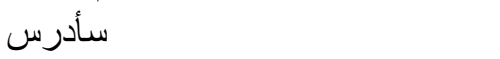 & I will study. \\
\hline سمعت كثيرا & I have heard a lot. \\
\hline 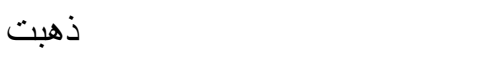 & I went. \\
\hline 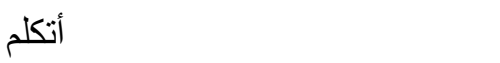 & I speak. \\
\hline 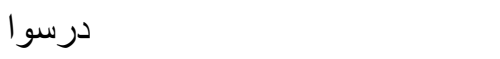 & They have studied. \\
\hline رايته & I saw him. \\
\hline 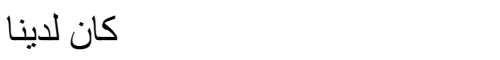 & We had. \\
\hline ساعدنا كثير ا & He helped us a lot. \\
\hline كان الحج سهلا & Hajj was fine. \\
\hline
\end{tabular}

Table 3. Typical produced patterns in function words class

\begin{tabular}{|c|c|}
\hline Example in Arabic Language & English translation of the Example \\
\hline في العاصمة & in the capital \\
\hline 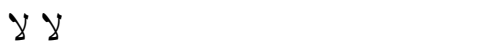 & No, no \\
\hline كلية التربية & college of education \\
\hline 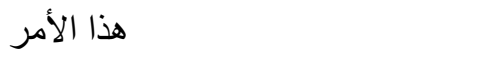 & this issue \\
\hline أو & or \\
\hline الفرق بين الغرب و المسلمين & the difference between Westerners and Muslims is... \\
\hline 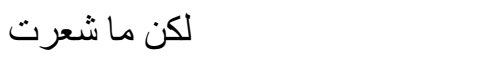 & but I didn’t fell \\
\hline 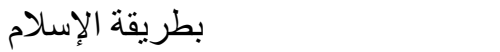 & in Islamic way \\
\hline تلاوة وتعبير إلخ... & recitation, dictation, etc. \\
\hline ل الآن & not now \\
\hline
\end{tabular}

Table 4. Atypical produced patterns in nouns class

\begin{tabular}{|c|c|}
\hline Example in Arabic Language & English translation of the Example \\
\hline أنا في أرجنتينا & I am in Argentina. \\
\hline درس/درسوا في الأرجنتين & They studies at Argentina. \\
\hline نحن كله جداد في الإسلام & We are all new to Islam. \\
\hline فطريقتين جيدة...جيدة؛ اللغة أو التربية & The two ways are good, good; language or education \\
\hline يختلف الأخلاق & Morals are different. \\
\hline العقل و الفكرة هن نفس الثشئ & Mind and ideas are both the same. \\
\hline أنتم تحفظ كثير & You memorize a lot. \\
\hline عبدالقادر من صومالي & Abdullqadir from Somali \\
\hline خمسة مو اد، سهل من الماضي & five course, easier than before \\
\hline ثلاثة مرة في الإسبوع & three times a week \\
\hline
\end{tabular}




\section{Macrothink}

International Journal of Linguistics

ISSN 1948-5425

2012, Vol. 4, No. 4

Table 5. Atypical produced patterns in verbs class

\begin{tabular}{|c|c|}
\hline Example in Arabic Language & English translation of the Example \\
\hline يوجد شاشـة & There is a projector. \\
\hline مافي فرق بيننا (لايوجد/ لافرق) & There is no difference between us. \\
\hline (إستخدام الجمل الأسمية أكثر من الفعلية) & $\begin{array}{l}\text { in Arabic language, verbal sentences are } \\
\text { more frequent than nominal sentences }\end{array}$ \\
\hline ندرة جمل المبتدأ و الخبر & very rare use of equational sentences \\
\hline سمعت كثير من المسلمين عندما يشهدون الكعبة، هم & I heard a lot about Muslims when they \\
\hline 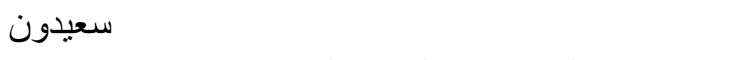 & Ind the Ka'abah, they look happy. \\
\hline الجنازة في المدينة المنورة... بطريقة إسلامية & funeral in Madinah... in Islamic way \\
\hline يوجد شاشـة & There is a projector. \\
\hline مافي فرق بيننا (لايوجد/ لافرق) & There is no difference between us. \\
\hline (إستخدام الجمل الأسمية & $\begin{array}{l}\text { in Arabic language, verbal sentences are } \\
\text { more frequent than nominal sentences }\end{array}$ \\
\hline ندرة جمل المبتدأ و الخبر & very rare use of equational sentences \\
\hline
\end{tabular}

Table 6. Atypical produced patterns in function words class

\begin{tabular}{|c|c|}
\hline Example in Arabic Language & English translation of the Example \\
\hline 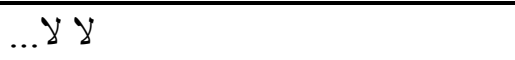 & No, no... \\
\hline قسم عقيدة & faith department \\
\hline كلية لغة العربية & College of Arabic Language \\
\hline نحن كله & all of us \\
\hline شعرت ما في شيئ & I felt nothing \\
\hline في مدينة المنورة & at Madinah \\
\hline ل ليس جيد & not good \\
\hline ... & No, no... \\
\hline قسم عقيدة & faith department \\
\hline كلية لغة العربية & College of Arabic Language \\
\hline
\end{tabular}

Tables (7- 12) present the selected data of case two where tables (7-9) present examples of the typical produced morphological patterns. On the other hand, tables (10-12) show examples of the atypical morphological patterns. Once again, tables $(7 \& 10)$ represent the nous class, tables $(8 \& 11)$ represent the verb class, and tables $(9 \& 12)$ represent the function word class. 
Table 7. Typical produced patterns in nouns class

\begin{tabular}{|c|c|}
\hline Example in Arabic Language & English translation of the Example \\
\hline طالب من بنين & a student from Benin \\
\hline معهد اللغة العربية & Arabic language institute \\
\hline اللغة الفرنسية الفية & French language \\
\hline أساعد المريض & I help the patient... \\
\hline من أسرتي & from my family \\
\hline مدينة طيبة & good city \\
\hline الرجل يذهب للأسرة & a man goes to the family \\
\hline هذا عربي، بلدان & this an Arabian, countries \\
\hline 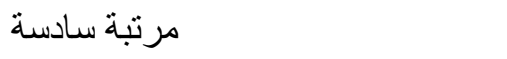 & sixth rank \\
\hline 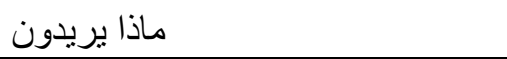 & what do they want \\
\hline
\end{tabular}

Table 8. Typical produced patterns in verbs class

\begin{tabular}{|c|c|}
\hline Example in Arabic Language & English translation of the Example \\
\hline ....كنت في بنين & I was in Benin. \\
\hline ع عرفت & I knew \\
\hline وصلت & I have arrived \\
\hline درست & I have studied \\
\hline 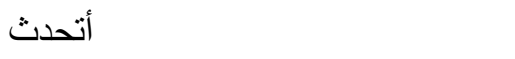 & I speak \\
\hline تتكون من & consists of \\
\hline 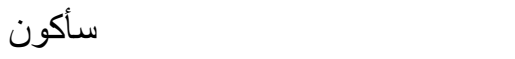 & I will be \\
\hline الذين درسوا & who studied \\
\hline 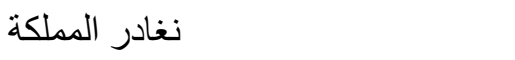 & leave the Kingdom \\
\hline لا أفهم، أنا أفكر & I do not understand, I think... \\
\hline
\end{tabular}

Table 9. Typical produced patterns in function words class

\begin{tabular}{|c|c|}
\hline Example in Arabic Language & English translation of the Example \\
\hline في جامعة الملك سعود & at King Saud University \\
\hline عرفت عن المملكة & I knew about the Kingdom \\
\hline ولكن هنا & but here \\
\hline 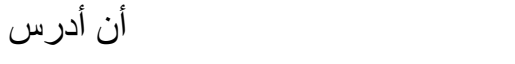 & to study \\
\hline 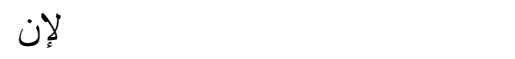 & Because \\
\hline حتى & Even \\
\hline 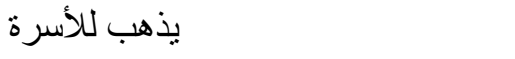 & go to the family \\
\hline هناك بعض الكلمات & there are some words \\
\hline إلا باللغة العربية & only in Arabic language \\
\hline إذا أهل... & if the family of... \\
\hline
\end{tabular}


Table 10. Atypical produced patterns in nouns class

\begin{tabular}{|c|c|}
\hline Example in Arabic Language & English translation of the Example \\
\hline المملكة، بلد وطيب و أحسن & the kingdom, good and better country \\
\hline أتخصص بجانب طبية & to be enrolled in a medical field \\
\hline أسرتي تتكون من أب و أم وأنا الثالثة & $\begin{array}{l}\text { my family consists of a father, mother, and I am } \\
\text { the } 3^{\text {rd }}\end{array}$ \\
\hline سأكون كبار ...سأكون مايحتاج أسرة & I will be the paterfamilias \\
\hline سأكون مربية بالبيت & I will be a housewife \\
\hline 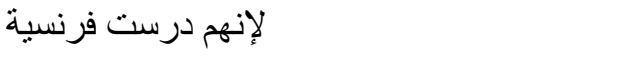 & because they have studies French language \\
\hline كثيرة مدن & a lot of cities \\
\hline ثلاثة أو أربعة مدينة للمسلمون & three or four cities for Muslims \\
\hline هذا مدينة، أحبها جيدا & This city, I like it too much \\
\hline الذي كان مشهورون، هي اللغة أفضل في العالم & $\begin{array}{l}\text { which were famous, it is the best language in the } \\
\text { world }\end{array}$ \\
\hline
\end{tabular}

Table 11. Atypical produced patterns in verbs class

\begin{tabular}{|c|c|}
\hline Example in Arabic Language & English translation of the Example \\
\hline درسها من حيث أتيت وحتى المتوسطة & I studied it since the first grade till the $9^{\text {th }}$ grade \\
\hline سأكون بها & I will do it \\
\hline يكون قويا & be strong \\
\hline سيكون قويا & will be strong \\
\hline كتب بالإنجليزية & books in English \\
\hline ترجمة بلغتهم & have been translated into their language \\
\hline هنا درسها & he studied it here \\
\hline درسها من حيث أتيت وحتى المتوسطة & I studied it since the first grade till the $9^{\text {th }}$ grade \\
\hline سأكون بها & I will do it \\
\hline يكون قويا & be strong \\
\hline
\end{tabular}

Table 12. Atypical produced patterns in function words class

\begin{tabular}{|c|c|}
\hline Example in Arabic Language & English translation of the Example \\
\hline في مستوى السادس & in the $6^{\text {th }}$ level \\
\hline أسمع المملكة العربية & I hear about the Kingdom of Saudi Arabia \\
\hline ذهبت في سوق & I went to a shop \\
\hline 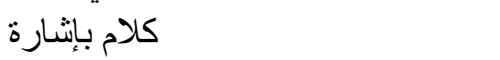 & communication using sign language \\
\hline هذه اللغة جعلو ا مرتبة سادسة & they make this language in the $6^{\text {th }}$ rank \\
\hline هذا الكتب & these books \\
\hline هم الذين يأتون شيئ جديد & they innovate things \\
\hline & $\begin{array}{l}\text { I have changed my mind } \\
\text { till they agreed }\end{array}$ \\
\hline سوق بطحاء وتميمي & Batha and Tamimy shops \\
\hline
\end{tabular}

Tables (13-16) illustrate the selected data for case three where tables (13-15) are examples of the typical produced morphological patterns, and table (16) consists of examples for atypical 
morphological patterns. While, tables (13-15) show noun class, verb class, and function word class respectively, table 16 consists of examples for the three classes of words in morphology.

Table 13. Typical produced patterns in nouns class

\begin{tabular}{|c|c|}
\hline Example in Arabic Language & English translation of the Example \\
\hline أيام العطلة & during holidays \\
\hline هذا السؤ ال مهم جدا & this question is important \\
\hline 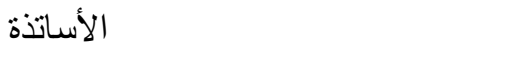 & Teachers \\
\hline تفاوت المستويات & variance in levels \\
\hline مع أبنائها & with its native speakers \\
\hline الناس يتكلمون & people speak \\
\hline نيجريا دولة قديمة في الإسلام & $\begin{array}{l}\text { Nigeria is an old country in embracing } \\
\text { Islam }\end{array}$ \\
\hline طموح كثيرة & many ambitions \\
\hline هذا الهدف هدف الطالب المخلص & this aim was the aim of a sincere student \\
\hline مجتهدون جداً & very hardworking \\
\hline
\end{tabular}

Table 14. Typical produced patterns in verbs class

\begin{tabular}{|c|c|}
\hline Example in Arabic Language & English translation of the Example \\
\hline سمعت بالجامعة عبر الزملاء & I heard about it from friends \\
\hline أناقشهم في الجامعة أنشة & I discuss with them in the university \\
\hline 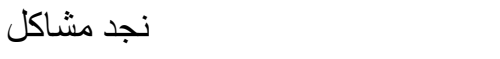 & we find problems \\
\hline قد درسو ا كثير ا & they have studied intensively \\
\hline لديهم حياء يمنعهم & they have shyness which stop them \\
\hline يقر أ كثيرا & He reads extensively \\
\hline نحتاج الى التطور من حيث الدين & we need development awareness regarding religion \\
\hline نحن نفكر في كيفية حلها & we think how to solve it \\
\hline 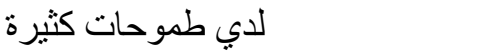 & I have many ambitions \\
\hline 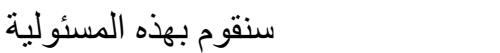 & we will carry this responsibility \\
\hline
\end{tabular}

Table 15. Typical produced patterns in function words class

\begin{tabular}{|c|c|}
\hline Example in Arabic Language & English translation of the Example \\
\hline سمعت بالجامعة & I heard about the university \\
\hline بمثل هذا المعهد & like this institute \\
\hline كلهم منميزين & all of them are distinguished \\
\hline في مستوى و احد & in the same level \\
\hline وخاصة مع ابنائها & especially with its native speakers \\
\hline لو كانو... لكنا.. & have they..., we were \\
\hline 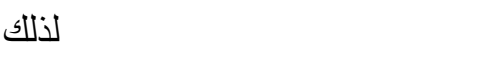 & So \\
\hline قد يكون... & it might be \\
\hline يوما بعد يوم & one day after another \\
\hline للأسف & unfortunately, \\
\hline
\end{tabular}


Table 16. Atypical produced patterns in content, verb and function class

\begin{tabular}{|c|c|}
\hline Example in Arabic Language & English translation of the Example \\
\hline مدر اس اللغة العربية نعد في أصابع اليد & $\begin{array}{l}\text { schools of Arabic language can be counted with } \\
\text { fingers }\end{array}$ \\
\hline (أب الإبن وو الد البنت)- عليه أن يتفق & $\begin{array}{l}\text { the father of the boy and the father of the girl- they } \\
\text { have to make an agreement between them }\end{array}$ \\
\hline أنشطات & Activities \\
\hline 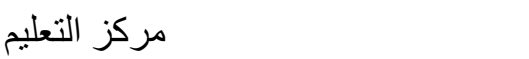 & teaching centre \\
\hline مدر اس اللغة العربية نعد في أصسابع اليد & $\begin{array}{l}\text { schools of Arabic language can be counted with } \\
\text { fingers }\end{array}$ \\
\hline (أب الإبن وو الد البنت)- عليه أن يتفق & $\begin{array}{l}\text { the father of the boy and the father of the girl- they } \\
\text { have to make an agreement between them }\end{array}$ \\
\hline 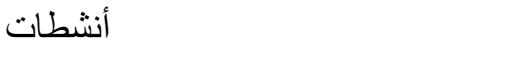 & Activities \\
\hline 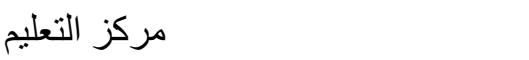 & teaching centre \\
\hline مدر اس اللغة العربية نعد في أصسابع اليد & $\begin{array}{l}\text { schools of Arabic language can be counted with } \\
\text { fingers }\end{array}$ \\
\hline (أب الإبن وو الد البنت)- عليه أن يتفق & $\begin{array}{l}\text { the father of the boy and the father of the girl- they } \\
\text { have to make an agreement between them }\end{array}$ \\
\hline
\end{tabular}

\section{Discussion}

In fact, acquiring and/or learning a second language is not very easy, yet not that difficult. However, to what extent it is difficult or easy can be determined by certain aspects, features, etc. including the environment of learning. To be brief, morphology as one component of language plays an important role not only at the level of vocabulary; it extends to integrate with phonology, syntax, semantics and pragmatics also. Thus, it is still argued regarding the mechanism(s) of acquiring morphological aspects and patterns. Yet, it is also controversial whether same learners of a certain language share exactly the same difficulties and also simple items of language. In this study, three young L2 acquirers of Arabic language between ages 22-30 have been compared and contrasted searching for similar and dissimilar typical and atypical produced morphological patterns.

In general, IAS, HBD, and AABF are more dissimilar to each other rather than similar to one another. Phonetically and phonologically, they all replace the sound [b-ta] with [t], [ث-tha] with [s], [₹-ain] with [a], and [ح-ha] with [h] especially HBD, and AABF, and with more insistence HBF who is still in level 2. It is actually strange why the IAS case who is from Argentina did not show such sound replacements, thought he is still in level 2.

Syntactically, IAS has just started level 2, so his syntax is still very poor in general. Say it another way, he only uses simple sentences, nominal ones, in spite of the fact that in Standard Arabic language, the typical use of sentence is verbal sentences in addition to the equational ones. It seems that he is still transferring his knowledge in his first language (Spanish), only nominal sentences.

In comparison, HBD is better than IAS regarding sentence structure. However, both cases 
still have serious syntactic errors in case-marking and in producing and comprehending compound, complex and ambiguous sentences even the simple ones.

Compared to the IAS and HBD, AABF who is a graduate shows only a very few syntactic errors and atypical productions and comprehended items as well.

To return to the main topic which is morphology, to start with content word class excluding verbs and with reference to figures $(1,4,7,10,13,16)$, IAS still have many problems regarding plurality, duality, gender, agreement between adjectives and nouns, number in general except simple numbers when used separately (no context) like (one, two, three, etc.). Unlike IAS, HBD produced a large number of the content words, but again with many atypical ones. Needless to say, for AAFB, he only has a few errors in patterns like broken plural and diminutives.

Regarding verbs, when looking at figures $(2,5,8,11,14,16)$, it is very clear that IAS uses a very limited number of verbs. It indicates that his lexicon is still very restricted. In contrast, HBD, produces more verbs, shows somehow good use of aspect and tense, but still have problems in verbs selection and appropriate use of verbs. For AABF, he shows very good use of verbs, tense and aspect except in the case of agreement and passive in certain patterns.

The last place where in these three cases can be compared and contrasted is function words. With reference to figures $(3,6,9,12,16)$, they all indicate again how the acquisition and learning of these patters by all L2 acquirers is greatly affected by their levels. Put it differently, AABF proves to be a competent user, he is even able to play with words and use them in ways that make his language more attractive. For the other two cases especially IAS, a very little number of functions words have been produced, whereas HBD has tried to manage using his knowledge regarding these patterns, but it seems that such patterns have not been processed well in a way that make its user use them effectively and correctly.

To conclude, IAS, HBD, and AABF are more different than each other, yet less similar to one another. These variances were shown clear through the produced morphological patterns by each one of them and may be affected by the period spent in the Kingdom of Saudi Arabia and amount of language being exposed to.

\section{Conclusion}

In this study, the researcher has investigated the morphology acquisition by L2 acquirers who speak three different languages as their first languages. To achieve this, the researcher has first recorded each case for 20-25 minutes, free speech and five minutes for each one (directed questions). The collected-data have been transcribed in Arabic, translated into English and then have been presented in figures in terms of content words excluding verbs, verbs and function words. Needless to say, this classification was based on the Arabic language system and the traditional works of Arab grammarians who accounted for morphology following such criterion.

Therefore, after analyzing the data, it has been shown that all the three cases still have atypical produced and comprehended morphological patterns which are governed by both the 
period spent in the Arabian country and the amount of the language each one of them has been exposed to. Regardless of the errors they make, IAS who has just started level 2, shows very poor communication and language comprehension. On the other hand, HBD shows poor communication skills, but good comprehension skills. It goes without saying, AABF who is a graduate student shows both good communication, production and comprehension of the language mainly here morphological patters.

Thus, it is recommended that more data from each case must be collected. Say it another way, a better selected methodology must be designed so that more reliable and valid results regarding morphology acquisition and/or learning could be found and inferred towards building a map-based framework for morphology acquisition in Arabic language.

\section{Acknowledgement}

Great thanks are due to the three students at the Arabic Language Institute, King Saud University, Riyadh, Saudi Arabia, who kindly agreed to participate in this study. http://ali.ksu.edu.sa/home

\section{References}

Abdullatif, M. M. (2000). An Introduction to Morphology Amman, Jordan: Dar Al-Massira Publishing- Distributing- Printing.

Abu-Aowdah, A. (2009). Morphology .Cairo : United Arab Company for marketing and exporting in cooperation with Open Qouds University.

Al-Enani, M. (2009). Arabic for Speaker of Other Languages. Amman: Dar Jareer Publishing.

Al-Ghamedy, M. R. (2009). Lectures in Morphology $2^{\text {nd }}$. Jeddah, Saudi Arabia: KHAWARIZM ACADEMIC.

Al-Hamadani, Kh. Z. (2010). Morphological Research-papers. Amman, Jordan: Dar Safa Publishing- Distributing.

Al-Hamlawy, A. (2002). Shatha'a Al-arf in the Art of Morphology. Jeddah : Dar Hera'a, Saudi Arabia.

Al-Hawamedah, R. Sh. M. (2010). The Simplified Morphology .Amman: Dar Safa Publishing- Distributing.

Al-Obaidy, Sh, A. (2008). Al-Ra'id (poineer) in Morphology .Banghzi, Libya: QarYounus University Publishing.

Al-Osaili, A. I. (1999). Psychological and Linguistic theories and Arabic Language Learning .Riyadh: King Fahd Library Publishing.

Al-Rajehy, A. (2004). Morphology Applications .Bairout, Lebanon: Dar Al-Nahdhah Al-Arabih.

Alssaid, A. (2010). Al-Moughny (the compensator) in Morphology. Amman: Dar Safa 
Publishing- Distributing.

Balboul, M. (2008). Word Strcuture in Arabic Language: Illustrations and Principles. Casablanca, Morroco: Fikr Publishing.

BENDJABALLAH, S., DRESSLER, W., PFEIFFER, O., \& VOEIKOVA, M. (Eds.). (2002). MORPHOLOGY 2000: SELECTED PAPERS FROM THE 9TH MORPHOLOGY MEETING, VIENNA, 24-28 FEBRUARY 2000. AMSTERDAM/PHILADELPHIA: JOHN BENJAMINS PUBLISHING COMPANY.

BROWN, D. (2007). Principles of Language Learning and Teaching (5 ed.). Pearson Education, Inc.

CHEJNE, A. G. (1969). THE ARABIC LANGUAGE: Its Role in History. MINNEAPOLIS: UNIVERSITY OF MINNESOTA PRESS [electronic version].

CLARK, E. V. (2009). First Language Acquisition (2nd ed.). Cambridge: CUP. http://dx.doi.org/10.1017/CBO9780511806698

Deen, K. U. (2005). Language Acquisition \& Language Disorders Series: The Acquisition of Swahili. (H. Clahsen, \& L. White, Eds.) Amsterdam/Philadelphia: John Benjamins Publishing Company.

Gass, S. M., \& Selinker, L. (2008). SECOND LANGUAGE ACQUISITION: An introductory course (3rd ed.). New York and London: Routledge.

Hassan, T.. (1984). Introduction to Arabic Language Acquisition for Non-native Speakers . Mecca: Omm Al-Qura Univesity, Saudi Arabia.

Holes, C. (2005). Modern Arabic Structures, Funntions and Varieties. Washington : Georgetown University Press.

Ibrahim, M. I. (2004). Directions for natvie-speakers' errors in non-inlfected items .Cairo: Cairo Press.

Issa, F. M. .(2000) .Morphology: An autonomous Approach .Amman, Jordan : Dar Al-Fikr for Press, Publishing, and Distributing.

Jacobson, P. F., \& Schwartz, R. G. (2005). English Past Tense Use in Bilingual Children With Language Impairment. American Journal of Speech-Language Pathology, 14(4), 313-323. Retrieved from EBSCOhost. (Accessed January 3, 2011). http://dx.doi.org/10.1044/1058-0360(2005/030)

Jia, G. (2003). The Acquisition of the English Plural Morpheme by Native Mandarin Chine-Speaking Children. Journal of Speech, Language \& Hearing Research, 46(6), 1297-1311. http://dx.doi.org/10.1044/1092-4388(2003-101). (Accessed January 3, 2011).

Lightbown, P. M., \& Spada, N. (2006). How Languages are Learned: Oxford Handbooks for Language Teachers (3 ed.). Oxford: Oxford University Press.

Loritz, D. (1999). How the Brain Evolved Language. Oxford : OUP. 


\section{Ml Macrothink}

International Journal of Linguistics

ISSN 1948-5425

2012, Vol. 4, No. 4

Mardiny, A. (2007). Simplified Morphology: Morphology Researchers in Arabic Language. Bairout, Damscus: Dar A'aiah, Lebanon, and Dar Al-Mahabah, Syrai.

Mitchell, T. F. (1962). Colloquial Arabic. New York : Hodder and Stoughton Ltd.

Moulton, J., \& Robinson, G. M. (1981). The Organization of Language. Cambridge: CUP. http://dx.doi.org/10.1017/CBO9780511529856

owens, J. (2006). A Linguistic History of Arabic. Oxford: Oxford University Press [electronic version]. http://dx.doi.org/10.1093/acprof:oso/9780199290826.001.0001

PACKARD, J. L. (2004). The Morphology of Chinese: A Linguistic and Cognitive Approach. Cambridge : CUP.

Paradis, J. (2005). Grammatical Morphology in Children Learning English as a Second Language: Implications of Similarities With Specific Language Impairment. Language, Speech \& Hearing Services in Schools, 36(3), 172-187. Retrieved from EBSCOhost. (Accessed January 3, 2011).

Parodi, T., Schwartz, B. D., \& Clahsen, H. (2004). On the L2 acquisition of the morphosyntax of German nominals[1]. Linguistics, 42(3), 669-705. Retrieved from EBSCOhost. (Accessed January 3, 2011). http://dx.doi.org/10.1515/ling.2004.022

Pedro Guijarro-Fuentes, M. P., \& Clibbens, J. (2008). Language Acquisition and Language Disorders Series:First Language Acquisition of Morphology and Syntax: Perspectives across languages and learners. (H. Clahsen, \& L. White, Eds.) Amsterdam / Philadelphia: John Benjamins Publishing Company.

Pinker, S. (1994). The Language Instinct: How the Mind Creats Language. New York : HarperPerennial, A Division of Harper Collins Publishers.

Qabbash, A. (1974). The Complete guide for Syntax, Morphology and Case-marking .Sana'a, Yemen : Al-Earshad Bookstor Library.

Rocca, S. (2007). Child Second Language Acquisition: A bi-directional study of English and Italian tense-aspect morphology. Amsterdam / Philadelphia: John Benjamins Publishing Company.

Ryding, K. C. (2005). A Reference Grammar of Modern Stnadard Arabic (Reference Grammars) (Vol. [electronic version]). Cambridge : Cambridge University Press. http://dx.doi.org/10.1017/CBO9780511486975

Salaberry, R., \& Shirai, Y. (2002). Language Acquisition \& Language Disorders Series: The L2 Acquisition of Tense-Aspect Morphology. (H. Clahsen, \& L. White, Eds.) Amsterdam/Philadelphia: John Benjamins Publishing Company.

SAVILLE-TROIKE, M. (2006). Introducing Second Language Acquisition. Cambridge : CUP.

Scovel, T. (1998). Oxford Introductions to Language Study: Psycholinguistics. (H. G. 
Widdowson, Ed.) Oxford: Oxford University Press.

Shimron, J. (2003). Language Acquisition \& Language Disorders Series: Language Processing and Acquisition in Languages of Semitic, Root-Based, Morphology. (H. Clahsen, \& L. White, Eds.) Amsterdam/Philadelphia: John Benjamins Publishing Company.

Shirai, Y. (2010). Semantic bias and morphological regularity in the acquisition of tense-aspect morphology: what is the relation?. Linguistics, 48(1), 171-194. http://dx.doi.org/10.1515/ling.2010.005

Singleton, D., \& Ryan, L. (2004). SECOND LANGUAGE ACQUISITION Series 9: Language Acquisition: The Age Factor (2nd ed.). (D. Singleton, T. College, Dublin, \& Ireland, Eds.) Clevedon, Buffalo, Toronto: MULTILINGUAL MATTERS LTD.

Soudi, A., Bosch, A. v., \& Neumann, G. (Eds.). (2007). Arabic Computational Morphology Knowledge-based and Empirical Methods. Dordrecht, the Netherlands: Springer. http://dx.doi.org/10.1007/978-1-4020-6046-5

Teaschner, T. (1983). The Sun is Feminine: A study on Language Acquisition in Bilingual Children: with 18 Figures. (W. J. Levelt, Ed.) Berlin, Heidleberg, New York, Tokyo: Springer Verlag.

Thackston, W. M. (2008). An Introduction to Koranic and Classical Arabic: An Elementary Grammar of the Language (Vol. [electronic version]). Ibex Publishers.

Watson, J. C. (2002). The Phonology and Morphology of Arabic. Oxford : Oxford University Press (OUP).

WHITE, L. (2003). Second Language Acquisition and Universal Grammar. Cambridge : CUP. http://dx.doi.org/10.1017/CBO9780511815065

Zahdi, A., Abu-Zaid, S. Ali, \& Al-Haroot, A. (2011). The comprehensive in Morphology. Kuwait, UAE, Egypt, Jordan: Al-Falah Books for Publishing and Distribution.

\section{Copyright Disclaimer}

Copyright reserved by the author(s).

This article is an open-access article distributed under the terms and conditions of the Creative Commons Attribution license (http://creativecommons.org/licenses/by/3.0/). 